\title{
Bibliometric Analysis of the School Middle Leaders: A Contemporary Review of Malaysia Education Perspective
}

\author{
Wan Fadhlurrahman W. Md. Rasidi ${ }^{*}$, Mydin Al Amin, Ismail Aziah \\ School of Educational Studies, Science University of Malaysia (USM), Pulau Pinang, Malaysia.
}

DOI: $10.4236 /$ ce.2020.115058

\begin{abstract}
This study is a continuation of the contemporary literature review undertaken by Harris et al. (2019) on the development of studies conducted in the context of middle leaders in the school. The previous review conducted by Harris et al. (2019) setting only the database of EBSCOHOST, SCOPUS and Web of Science (WoS), it is expected to have the potential of research and articles related to school middle leaders are published in other journals in the context of Malaysian education. Hence, the purpose of this study is to further explore and identify empirical articles related to the school middle leaders in Malaysia from 2010 until 2019. This contemporary literature review is adapting a bibliometric approach and thematic analysis. The study has resulted in a search of 29 articles related to middle leaders in the context of Malaysian education compared to only one cited by previous researchers.
\end{abstract}

\section{Keywords}

Middle Leaders, Middle Leadership, Committee Head, Head of Department, Senior Teachers, Subject Coordinator, Schools in Malaysia

\section{Introduction}

The role of school middle leader is gaining attention, especially from researchers in the field of leadership. There are various leadership models involving middle leaders such as instructional leadership, distribution leadership, teacher leadership and school leadership that are being globally explored (Gumus et al., 2018; Tian, Risku, \& Colin, 2016; Wenner \& Campbell, 2017). Even in the Malaysian Education Development Plan (PPPM), 2013-2015 leadership contexts involving middle leaders have begun to be taken seriously by the Ministry of Education Malaysia (MOE, 2013). Middle leaders not only carry out administrative tasks as directed by school leaders, but they are also directly involved in teaching and learning in the classroom just like other teachers. Thus, the presence of middle leaders in the school leadership line should be taken seriously in addition to the tendency for past studies which only focus solely on their functions and roles in the school (Bennett et al., 2003).

Harris et al. (2019) argued that previous research trends are less focused on a variety of research areas involving middle leaders other than their roles and responsibilities. Studies of middle leaders should be conducted in a broader scope and context (Gumus et al., 2018). Therefore, this study was a continuation of the literature review undertaken by Harris et al. (2019) on the development of studies conducted in the context of the middle leaders in the school. However, this review will focus on the highlights of studies conducted in Malaysia 
alone that have not been explored by Harris et al. (2019). This study adopted a bibliometric literature review approach from 2010 to 2019.

\section{Problem Statement}

Using a bibliometric method approach, Harris et al. (2019) found a significant gap in the number of studies related to the school middle leaders between 2003 and 2017. The Asian region showed a positive trend when registering an increased number of articles published from 7\% to 34\% compared to Europe, Oceania, Middle East and North America. Although this enhancement was very good, there is a significant gap between Asian countries when conducting studies on school middle leaders. There is only one article which was listed from Malaysia as compared to other Asian countries such as Hong Kong and Singapore (Harris et al., 2019). The only article listed in the study of Harris et al. (2019) discussing the qualitative studies of middle leaders at an international school located in Johor. Hence, it is necessary to highlight in-depth studies with a broader scope of school middle leaders in the context of education in Malaysia.

The middle leaders' leadership in Malaysia should also start to make a positive impact since the MOE began focusing on capacity building of middle leaders in the Education Development Master Plan (PIPP) launched in 2006 and ending in 2010 (MOE, 2013). The professionalism development agenda of the middle leaders in Malaysia continued in PPPM 2013-2025, where the ministry's work shifted from top-down to bottom-up which notice the direct involvement of schools' middle leaders in leadership at the school level. Since the previous study conducted by Harris et al. (2019) based only on databases from EBSCOHOST, SCOPUS and Web of Science (WoS), it is expected that there will be more studies and articles related to middle leaders in Malaysia which have published in other journals including master and doctoral thesis reports. Thus, the purpose of this contemporary literature review is to identify scientific studies of middle leaders that have not been explored by Harris et al. (2019) in the context of education in Malaysia.

\section{Research Objectives}

This contemporary literature review aims to explore and identify studies related to school middle leaders conducted in Malaysia that have not been explored by Harris et al. (2019). Specifically, the focus of the study was during the last decade between 2010 and 2019, postPIPP 2006-2010 and PPPM era 2013-2025, which are two of the major educational plans in the Malaysian education system (MOE, 2013). The main purpose of this study was to identify studies of middle leaders by using adapted bibliometric and thematic analysis. Besides, the findings of this study can also provide information on the location, methodology and purpose of the listed studies that can serve as a guide for future researchers in the field of educational leadership and management. The research questions that guide this contemporary highlights are as follows:

1) To what extent have studies of school middle leaders been empirically conducted since 2010 in the context of Malaysian education?

2) What is the tendency of field study in middle leaders in Malaysian education context?

Based on the contemporary study survey carried out by Harris et al. (2019); there are several limitations found that may curb the search for articles related to middle leadership in 
Malaysia. These include the establishment that only English-language articles listed in the EBSCOHOST, SCOPUS and Web of Science (WoS) databases are the main criteria (Harris et al., 2019). Therefore, the search for articles in other languages should also be considered (Hallinger \& Cheng, 2015). Thus, to explore the knowledge of the school middle leaders in Malaysia, the researchers set Malay language as an additional criterion of search related articles as well as English. Besides, local databases such as MyJurnal by the Malaysian Citation Center (MCC), Malaysian Theses Online (MyTO) and Google Scholar are listed as databases for article searches other than SCOPUS and Web of Science (WoS).

Harris et al. (2019) also found that studies and evidence on the relationship between middle leaders to organizational change and student learning are still limited. Therefore, through this contemporary highlight, several articles are listed through modified search settings based on the study by Harris et al. (2019) aimed at exploring the empirical studies that have been carried out on middle leaders in Malaysia between 2010 and 2019.

\section{The Importance of Empirical Studies among Middle Leaders in Malaysia}

Middle leaders are potential school leaders who can replace existing leadership (Fusarelli, Fusarelli, \& Riddick, 2018; Peter-Hawkins, Reed, \& Kingsberry, 2018; Rohana, Marthada, \& Halimah, 2018). Studies in High Performing School (SBT) in Malaysia support the fact that middle leaders are the most qualified group to replace school principals and headmasters when the appropriate training provided (MohdIzham \& Shuhaida, 2017). As middle leaders are the leaders of teachers, they are also involved in the instructional leadership in schools. Schools need to be led by leaders who prioritize instructional leadership as there is evidence that there is a link between teachers' efficacy and instructional leadership (Abdul Ghani, Ekerim \& Ying-Leh Ling, 2019).

In the context of education in Malaysia, principals and headmasters determine the success and effectiveness of a school (Mohd Ibrahim, Mohammed Sani, \& Rosemawati, 2015; Mohd Yusri \& Aziz, 2014; Jamelaa, 2012; Hallinger, 2011). However, principals and headmasters bound by the overall management commitment of the school institution; hence resulting in a school governance scenario in Malaysia that is more administrative than instructional (OECD Talis, 2009). Inspection report by The Education Inspectors and Quality Assurance of Malaysia (JNJK) shows that the quality of instructional leadership of principals and teachers in Malaysia is at an average level of $67.79 \%$ (JNJK, 2009). The same report states that 35\% of teachers in Malaysia are unsure of the ability of principals and headmasters as a source of reference on current policies and strategies for teaching. This gives a new dimension of opportunities to the middle leaders in Malaysia to fill the gaps in existing instructional leadership by principals and headmasters.

\section{Methodology}

This contemporary literature review adapts bibliometric methods and thematic analysis. A bibliometric is an approach in which researchers can make literature review by referring to the summary of studies, focused keywords and the references (Gumus et al., 2018). Previous researchers use the information on the authors, info on journals, countries of origin, institutions involved and as a comparison method in this bibliometric approach (Gumus et al., 2018; Harris et al., 2019). The information obtained by the bibliometric approach is fundamental and is used as a general review of the middle leaders. Hence, the thematic analysis was made to secure the deeper and detailed information about the articles listed 
(Gumus et al., 2018). The matters considered in this thematic analysis include geographic information, methodology, the focus of the study, findings as well as the study context.

The objective of this contemporary literature review is to explore the articles related to middle leaders in the context of education in Malaysia that have not been explored in the previous reviewed by Harris et al. (2019). Several settings were outlined in this bibliometric approach and the thematic analysis. The settings include the selection of databases, keyword selection, setting of search criteria, article selection and analysis. Researchers set articles in Malay and English that are listed in SCOPUS, Web of Science (WoS), MyJurnal, Malaysian. Theses Online (MyTO) and Google Scholar as the database for article search. Articles published between 2010 and 2019 have been identified to be explored as complementary to the study by Harris et al. (2019). The following are the steps taken by the authors through the bibliometric approach and analytical analysis in conducting this contemporary literature review as shown in Table 1 below.

Table 1 . The steps taken in conducting contemporary literature review using bibliometric apprach.

Next is the keyword selection of middle leaders in Malaysia's educational context is defined. Main keywords are "middle leaders", "middle leadership", "committee heads", "senior teachers", "subject coordinator" with a combination of any keyword. The word "Malaysia" is also placed together to narrow down the search. The keywords listed are tested in the selected database. The tests are conducted to determine the accuracy of appropriate keywords and can provide actual input in the context of the study. To enhance search accuracy, logical operators such as "OR" and "AND" are used in the search. The appropriate search keyword finalized and listed as "middle leader", "middle manager", "head of the committee", "subject panel", "senior subject teacher", "middle leadership" and "senior teacher".

The setting of article selection criteria is carried out with adapted four main steps used in the bibliometric approach (Harris et al., 2019). Firstly, the search keyword is included in the listed journal database, the search year limit between 2010 and 2019 only and the context of the study is related to the middle school leaders in Malaysia. The first step of the search found a total of 75 articles out of 5 databases of journal publishing and articles. There are several unrelated articles and deviated from this literature review objective and need to be filtered out. Secondly, articles that write explicitly the keyword of middle leaders or middle leadership in the title or abstract of the study had been selected. The article selection criterion at this second step has listed a total of 62 articles. Thirdly, only research papers implemented in Malaysian national schools are selected. Articles from abroad and not studying middle leadership is excluded. At this stage, a total of 43 articles were successfully collected. The final step, only empirical studies are preferred at this stage. Concept papers, personal opinions, publishing articles in blogs and university official pages are not accepted. The final lists of total downloaded articles are as many as 29 articles (Figure $1 \&$ Appendix).

Figure 1. Bibliometric approach of article selection. Adaptation from Harris et al. (2019). 
As a way to store data systematically and securely, the Google Drive site is selected. Google Drive selection versus other data storage methods is due to better functionality and data security. Google Drive can serve as Microsoft Excel through the Google Sheet apps that can keep the data systematically (sorting and filtering functions) without limits and services offered are free of charge. Researchers are also experienced using Google Drive and it is very practical because of the integration of data storage via the cloud without anxiety for data loss. Furthermore, it can be accessed anywhere easily.

Then, the thematic analysis was done for all 29 articles that were collected in the Google Drive site. 10 themes have been set for the analysis as follows: 1) Year of study; 2) Name of researchers; 3) Title of study; 4) Name of journal; 5) State/region where the study is conducted; 6) Research methodology; 7) Method of collection and analysis of data; 8) Purposes of research; 9) The findings and research analysis; 10) Research limitation. Using an Excel application in Google Drive, all articles through the screening and filtering process based on a specified theme. The following sections discussed the findings and implications of the surveys that were carried out.

\section{Results and Discussion}

A comprehensive thematic analysis of 29 out of total 43 articles related to school middle leaders in Malaysia was made based on results from the bibliometric analysis. The purpose of this thematic analysis is to provide general information on studies that have conducted on middle leaders' leadership over the last decade. This general information includes the year of publication, journal information and study zone which are optional to the study. Subsequent discussions on the content of the study, the methodology of the study, the method of collecting/analyzing the data and the purpose of the study obtained from contemporary highlights are compared.

According to Table 2, during the last decade between 2010 and 2019; out of a total of 29 articles on school middle leaders in Malaysia, only in 2015, there is no publication or study conducted. Studies on intermediate leadership show an increasing trend since 2010 with 2018 and 2019 showing the highest number of article publications. On average, the number of articles published is 2.9 articles per year. This reflects the ongoing interest of those directly involved in the field of school leadership in Malaysia. Relatively, the previous finding by Harris et al. (2019) found only one article related to middle leadership in the context of Malaysian education. Modifying the article selection criteria clearly helps provide a broader scope of research to complement the findings of previous studies that list some limitations (Harris et al., 2019).

All of these 29 articles have been published in 18 different journals, including four (4) articles that are master and $\mathrm{PhD}$ dissertations. Over $80 \%$ of these articles have published in journals related to leadership, education and academics. Only three (3) articles published in non-related journals, the Malaysian Journal of Society and Space, the Journal of Technology (Social Science), and the Malaysian Journal of Social Science and Humanities. Based on Table 3, the Journal of Educational Leadership is the most widely published journal on school middle leaders in Malaysia. It was particularly exciting when seven (7) articles listed in the Scopus index journal. Journals that focused on educational leadership such as Educational Leader, International Journal of Management Studies and School Leadership \& Management also known as School Organization Journal only publish two (2) articles on 
middle leaders leadership in Malaysia. This number is significantly small since on average there is only 0.2 articles are published each year between 2010 and 2019.

Almost $60 \%$ of articles have published in journals that are not in the field of leadership and education management. Such journals usually select only one or two topics beyond their scope for publication, for example, Journal of Education and Training and Academic Research in Progressive Education and Development only publish one article related to school middle leaders. Both journals are Scopus and WoS indexed journals (Harris et al., 2019).

In terms of study zone, thematic analysis has listed six (6) study zones in Malaysia namely the northern zone (Perlis, Kedah, Penang, Perak) central zone (Selangor, Kuala Lumpur, Putrajaya, Negeri Sembilan), the east coast zone (Pahang, Terengganu, Kelantan), the southern zone (Johor, Malacca), the Sabah/Sarawak zone, and a zone labelled "unclassified". Table 4 shows 11 articles in the category "unclassified" of zones due to the study methodology taking into account samples from combinations of zones and throughout Malaysia. The total studies of middle leaders in the northern, southern and Sabah/Sarawak are five (5), three (3) and two (2); respectively. Meanwhile, the middle and east zone share the same number of articles which is four (4). Besides, the two (2) articles published from the southern has included the only study listed in Harris et al. (2019).

Table 2. Number of studies per year.

Table 3. Number of studies per journal.

Table 4. Number of studies by zone.

The content analysis of the 29 listed articles provides an overview of the methodology used in the conducted research. All of the articles listed compiled in three (3) main methodological categories; namely qualitative, quantitative approach and a combination of the two. Table 5 shows the tendency of the selection of research methodologies related to school middle leaders in Malaysia. Nearly $60 \%$ of the studies conducted using quantitative approaches followed by qualitative (24\%) and combined methods (16\%). Contrary to the findings of previous studies, the qualitative approach dominates the methodology used by most of the overseas researchers in particular (Harris et al., 2019). Qualitative approaches can provide an in-depth explanation in the field of school middle leaders (De Nobile, 2018; Harris et al., 2019).

Researchers in Malaysia are more comfortable in using questionnaires as a method of data collection. Almost 50\% of the studies conducted by using questionnaires (Table 6) as compared to only $10 \%$ using the interview method. The only study of middle leaders in Malaysia used the systematic literature review methodology in reviewing instructional 
leadership is the study by Harris, Jones, Adams, \& Cheah (2018). There is a high potential for researchers in Malaysia to adopt the systematic review of the study as this technique is an approach that enables the comparison of articles in various aspects (Gumus et al., 2018). However, to enhance the understanding and generalization of middle leaders in Malaysia, a qualitative approach with data collection methods such as interviews, document analysis and observation is recommended (De Nobile, 2017; De Nobile, 2018).

Next, all 29 articles were categorized according to five (5) key themes in the study of school middle leaders in Malaysia. These categories are based on the purpose of the research stated in the objective and the abstract of the study. Table 7 shows the study categories adapted from the contemporary highlights of Harris et al. (2019). Studies in the category of roles and functions of middle leaders dominate with almost $50 \%$ of total studies in this category. This is in agreement with findings of middle leaders in the context of overseas education that still focus on studies of the functions and roles played by middle leaders (Bennett et al., 2007; Harris et al., 2019). Subsequent studies of distributed leadership, learning/professional development and work satisfaction of the respective leaders produced four (4) articles in Malaysia from 2010 to 2019. Only three (3) articles on the quality of intermediate leader learning obtained through this contemporary survey.

Table 5. Number of articles by method.

Table 6. Number of articles by data collection tools.

Table 7. Summary of category of articles.

Practical Implications

The findings of this study are very helpful in providing additional support and information regarding school middle leaders in Malaysia. The potential of middle leaders in Malaysia should be bred through more empirical studies. Researchers in the field of education management and leadership in Malaysia need to focus on studies on the quality of teaching and professional learning as this analysis highlights that it is still limited. The themes set out in the selection criteria of this study can lead other researchers to focus and find research gaps for improvement in research related to school middle leaders.

\section{Limitation of Research}

Although the scope of article searches on middle leaders in Malaysia has been broadened compared to previous highlights by Harris et al. (2019), but there are still some limitations to the conducted review. The first limitation is a very limited local database that relies solely on MyJurnal by the Center for Malaysian Studies (MCC) and Malaysia Thesis Online (MyTO). It is proposed that the search for articles need to be expanded and include the database of 
universities in Malaysia. Secondly, similar to the criteria set by Bennett et al. (2007) and Harris et al. (2019) academic writings such as books, proceedings papers and opinions of academic figures on blog sites, social sites and official interviews are ignored. There may be sources of articles that may support a study highlight of uncharted school middle leaders.

Therefore, to complement future studies, it is proposed that triangulation of findings can be conducted with other alternative sources including social media that is gaining prominence among researchers. Next, the bibliometric analysis approaches are still categorized as simple and not in-depth approaches which used to derive the initial theme only (Gumus et al., 2018). Defining search keywords is critical and determinant of search. Therefore, to address this weakness, it is advisable to list as many keywords as possible for middle leaders and not focus solely on positions or roles. The other search suggestions relevant to school middle leaders in the context of Malaysian education are specialist teachers, grade level coordinators, resource teachers, senior teachers and excellent teachers as well as two key keywords used in this survey: Head of Committee and Subject Senior Teacher.

\section{Summary}

This contemporary review of the literature clearly shows that there are empirical studies of school middle leaders in the context of education in Malaysia. The trend of published articles shows a positive increment and indicates the recent development of educational leadership research in Malaysia. Since Bennett et al. (2003) highlight the study of middle leaders; subsequent efforts by Harris et al. (2019) found that articles from Malaysia were limited. Therefore, the findings of this study are very helpful in providing additional support and information regarding school middle leaders in Malaysia. However, the extent to which studies at the mid-level leadership have contributed to the education system in Malaysia, especially in the field of educational leadership, is still debatable.

\section{Conflicts of Interest}

The authors declare no conflicts of interest regarding the publication of this paper. 


\section{References}

\section{Undergraduate Thesis}

Setiawan, A. R. (2017, February 24). Penerapan Pendekatan Saintifik untuk Melatihkan Literasi Saintifik dalam Domain Kompetensi pada Topik Gerak Lurus di Sekolah Menengah Pertama. Undergraduate Thesis. Bandung: Universitas Pendidikan Indonesia. URL: http://repository.upi.edu/29074/

\section{Academic Journal}

Setiawan, A. R. (2020, April 21). Lembar Kegiatan Literasi Saintifik untuk Pembelajaran Jarak Jauh Topik Penyakit Coronavirus 2019 (COVID-19). Edukatif: Jurnal Ilmu Pendidikan, 02(01): 28-37. DOI: https://doi.org/10.31004/edukatif.v2i1.80

Setiawan, A. R. (2020, March 01). Pendidikan Literasi Finansial Melalui Pembelajaran Fiqh Mu'āmalāt Berbasis Kitab Kuning. Nazhruna: Jurnal Pendidikan Islam, 03(01): 138-159. DOI: https://dx.doi.org/10.31538/nzh.v3i1.522

Setiawan, A. R. (2020, January 24). Pembelajaran Tematik Berorientasi Literasi Saintifik. Jurnal Basicedu: Journal of Elementary Education, 04(01): 71-80. URL: https://jbasic.org/index.php/basicedu/article/view/298

Setiawan, A. R. (2019, December 30). Instrumen Penilaian Pembelajaran Fiqh Mu'āmalāt Berorientasi Literasi Finansial. Eklektik: Jurnal Pendidikan Ekonomi dan Kewirausahaan, 02(02): 258-272. DOI: http://dx.doi.org/10.24014/ekl.v2i2.8117

Setiawan, A. R. (2019, December 20). Literasi Saintifik Berdasarkan Kecerdasan Majemuk dan Motivasi Belajar. Media Penelitian Pendidikan: Jurnal Penelitian dalam Bidang Pendidikan dan Pengajaran, 13(02): 126-137. DOI: http://dx.doi.org/10.26877/mpp.v13i2.4913

Setiawan, A. R.; Puspaningrum, Mita; \& Umam, Khoirul. (2019, December 06). Pembelajaran Fiqh Mu'āmalāt Berorientasi Literasi Finansial. Tarbawy: Indonesian Journal of Islamic Education, 06(02): 187-102. URL: https://ejournal.upi.edu/index.php/tarbawy/article/view/20887

Setiawan, A. R. (2019, October 02). Efektivitas Pembelajaran Biologi Berorientasi Literasi Saintifik. Thabiea : Journal of Natural Science Teaching, 02 (02): 83-94. DOI: http://dx.doi.org/10.21043/thabiea.v2i2.5345

Setiawan, A. R. (2019, September 30). Instrumen Penilaian untuk Pembelajaran Ekologi Berorientasi Literasi Saintifik. Assimilation: Indonesian Journal of Biology Education, 02(02): 42-46. DOI: https://dx.doi.org/10.17509/aijbe.v2i2.19250

Setiawan, A. R.; Mufassaroh, Arij Zulfi. (2019, June 28). Menyusun Soal Literasi Saintifik untuk Pembelajaran Biologi Topik Plantae dan Animalia. BIOSFER: Jurnal Biologi dan Pendidikan Biologi, 04(01): 33-40. URL: http://dx.doi.org/10.23969/biosfer.v4i1.1484

Setiawan, A. R. (2019, June 26). Peningkatan Literasi Saintifik melalui Pembelajaran Biologi Menggunakan Pendekatan Saintifik. Journal of Biology Education, 02(01): 223-235. URL:

http://journal.stainkudus.ac.id/index.php/jbe/article/view/5278

Setiawan, A. R.; Utari, Setiya; Nugraha, Muhamad Gina. (2017, September 22).

Mengonstruksi Rancangan Soal Domain Kompetensi Literasi Saintifik Siswa SMP Kelas VIII pada Topik Gerak Lurus. Wahana Pendidikan Fisika, 02(02): 44-48. URL: https://ejournal.upi.edu/index.php/WPF/article/view/8277/0 


\section{Proceeding Article}

Setiawan, A. R. (2020, April 20). Menyusun Instrumen Penilaian untuk Pembelajaran Ekologi Berorientasi Literasi Saintifik. Prosiding Seminar Nasional dan Workshop Biologi-IPA dan Pembelajaran Ke-4 (SnoWBel IV): 241-9. ISBN : 978-602-470-170-3 \& e-ISBN : 978-602-470-171-0.

Setiawan, A. R. (2020, February 18). Menyusun Instrumen Penilaian untuk Pembelajaran Topik Lingkungan Berorientasi Literasi Saintifik. Prosiding Seminar Nasional Fisika (SiNaFi) 2019: 15-21. URL:

http://proceedings.upi.edu/index.php/sinafi/article/view/563

Setiawan, A. R. (2020, January 17). Penggunaan Mabadi 'Asyroh dalam Pembelajaran Biologi untuk Meningkatkan Motivasi dan Hasil Belajar. Prosiding Seminar Nasional Biologi 2019 Inovasi Penelitian dan Pembelajaran Biologi III (IP2B III): 158-164. URL:

http://semnasbiologi.conference.unesa.ac.id/ocs/index.php/semnasbio/IP2BII I/paper/viewFile/11/21

Setiawan, A. R. (2020, January 17). Upaya Meningkatkan Motivasi Belajar dalam Pembelajaran Ilmu Pengetahuan Alam (IPA) Melalui Bacaan Populer. Prosiding Seminar Nasional Biologi 2019 Inovasi Penelitian dan Pembelajaran Biologi III (IP2B III): 154-157. URL:

http://semnasbiologi.conference.unesa.ac.id/ocs/index.php/semnasbio/IP2BII I/paper/viewFile/5/51

Setiawan, A. R. (2020, January 17). Penerapan Pendekatan Saintifik dalam Pembelajaran Biologi sebagai Upaya Melatih Literasi Saintifik. Prosiding Seminar Nasional Biologi 2019 Inovasi Penelitian dan Pembelajaran Biologi III (IP2B III): 140-145. URL:

http://semnasbiologi.conference.unesa.ac.id/ocs/index.php/semnasbio/IP2BII I/paper/viewFile/6/19

Setiawan, A. R. (2019, October 14). Penyusunan Program Pembelajaran Biologi Berorientasi Literasi Saintifik. Seminar Nasional Sains \& Entrepreneurship VI (SNSE VI): 255-1-8. URL: http://conference.upgris.ac.id/index.php/snse/article/view/255

Setiawan, A. R. (2019, May 07). Penerapan Pendekatan Saintifik untuk Melatih Literasi Saintifik dalam Domain Kompetensi pada Topik Gerak Lurus di Sekolah Menengah Pertama. Prosiding Seminar Nasional Fisika (SiNaFi) 2018: 7 13. URL: http://proceedings.upi.edu/index.php/sinafi/article/view/355

\section{Colloquium Presentation}

Setiawan, A. R. (2019, November 23). Profil Literasi Saintifik Berdasarkan Kecerdasan Majemuk dan Motivasi Belajar. Seminar Nasional Fisika V (SiNaFi 5.0), Universitas Pendidikan Indonesia (UPI). DOI: https://dx.doi.org/10.35542/osf.io/m7n95

Setiawan, A. R. (2019, November 23). Menyusun Instrumen Penilaian untuk Pembelajaran Topik Lingkungan Berorientasi Literasi Saintifik. Seminar Nasional Fisika V (SiNaFi 5.0), Universitas Pendidikan Indonesia (UPI). DOI: https://dx.doi.org/10.35542/osf.io/sc6d2

Setiawan, A. R. (2019, November 23). Analisis Keabsahan dan Keandalan Science Motivation Questionnaire II (SMQ II) Versi Bahasa Indonesia. Seminar Nasional Fisika V (SiNaFi 5.0), Universitas Pendidikan Indonesia (UPI). DOI: https://doi.org/10.31237/osf.io/6zeph 
Setiawan, A. R. (2019, October 05). Menyusun Instrumen Penilaian untuk Pembelajaran Ekologi Berorientasi Literasi Saintifik. Seminar Nasional \& Workshop Biologi, IPA, dan Pembelajarannya ke-4 (SnoWBel IV), Universitas Negeri Malang (UM). DOI: https://dx.doi.org/10.13140/RG.2.2.21931.39206

Setiawan, A. R. (2019, August 21). Penyusunan Program Pembelajaran Biologi Berorientasi Literasi Saintifik. Seminar Nasional Sains \& Entrepreneurship VI (SNSE VI), Universitas PGRI Semarang (UPGRIS). DOI: https://dx.doi.org/10.13140/RG.2.2.13716.86400

Setiawan, A. R. (2019, March 23). Upaya Meningkatkan Motivasi Belajar dalam Pembelajaran Ilmu Pengetahuan Alam (IPA) Melalui Bacaan Populer. Seminar Nasional Biologi 2019 Inovasi Penelitian dan Pembelajaran Biologi III (IP2B III), Universitas Negeri Surabaya (UNESA). DOI: https://dx.doi.org/10.13140/RG.2.2.13087.71847

Setiawan, A. R. (2019, March 23). Penerapan Pendekatan Saintifik dalam Pembelajaran Biologi sebagai Upaya Melatih Literasi Saintifik Siswa Sekolah Menengah. Seminar Nasional Biologi 2019 Inovasi Penelitian dan Pembelajaran Biologi III (IP2B III), Universitas Negeri Surabaya (UNESA). DOI: https://dx.doi.org/10.13140/RG.2.2.19798.60484

Setiawan, A. R. (2019, March 23). Penggunaan Naḍom Mabādī 'Asyroh dalam Pembelajaran Biologi untuk Meningkatkan Motivasi dan Hasil Belajar. Seminar Nasional Biologi 2019 Inovasi Penelitian dan Pembelajaran Biologi III (IP2B III), Universitas Negeri Surabaya (UNESA). DOI: https://dx.doi.org/10.13140/RG.2.2.33220.37763

Setiawan, A. R. (2018, November 24). Penerapan Pendekatan Saintifik untuk Melatih Literasi Saintifik dalam Domain Kompetensi pada Topik Gerak Lurus di Sekolah Menengah Pertama. Seminar Nasional Fisika ke-4 (SiNaFi IV), Universitas Pendidikan Indonesia (UPI). DOI: https://dx.doi.org/10.13140/RG.2.2.23154.04809

Setiawan, A. R.; Utari, Setiya; Nugraha, Muhamad Gina. (2016, December 17).

Mengonstruksi Rancangan Soal Domain Kompetensi Literasi Saintifik Siswa SMP Kelas VIII pada Topik Gerak Lurus. Seminar Nasional Fisika ke-2 (SiNaFi II), Universitas Pendidikan Indonesia (UPI). DOI: https://dx.doi.org/10.13140/RG.2.2.31856.10246/1

\section{- Blog Post (Kirana $\boldsymbol{r}$ Azalea)}

Setiawan, A. R. (2012, 28 Agustuts). Meniti Interaksi Hati [Tribute to Dahlan Salim Zarkasyi]. Kirana $\mathcal{V}$ Azalea. URL: https://adibrs.blogspot.com/2012/08/alquran.html.

Setiawan, A. R. (2012, 31 Desember). Judge A Book by Its Cover. Kirana $\mathcal{V}$ Azalea. URL: https://adibrs.blogspot.com/2012/12/kretek.html.

Setiawan, A. R. (2013, 09 Maret). Kirana Tanpa Sirna. Kirana $\mathcal{V}$ Azalea. URL: https://adibrs.blogspot.com/2013/03/turoichan.html.

Setiawan, A. R. (2013, 07 April). Kok Tiongkok?. Kirana $\mathscr{V}$ Azalea. URL: https://adibrs.blogspot.com/2013/04/tiongkok.html.

Setiawan, A. R. (2013, 11 Mei). Butcah Mbeling. Kirana $\mathscr{P}$ Azalea. URL: https://adibrs.blogspot.com/2013/05/feynman.html. 
Setiawan, A. R. (2013, 11 Juni). Senandung Risalah Tanjung Indah. Kirana $\mathscr{P}$ Azalea. URL: https://adibrs.blogspot.com/2013/06/maryam.html.

Setiawan, A. R. (2013, 15 Juli). Menjilati Yuli. Kirana $\mathscr{P}$ Azalea. URL: https://adibrs.blogspot.com/2013/07/yuli.html.

Setiawan, A. R. (2013, 19 Juli). Karena Lelaki Bukan Pengecut. Kirana $\mathscr{V}$ Azalea. URL: https://adibrs.blogspot.com/2013/07/brian.html.

Setiawan, A. R. (2013, 26 Agustus). Bathari Jawi. Kirana $\mathscr{V}$ Azalea. URL: https://adibrs.blogspot.com/2013/08/sri.html.

Setiawan, A. R. (2013, 05 September). Pelanggam Azam. Kirana $\mathscr{V}$ Azalea. URL: https://adibrs.blogspot.com/2013/09/farrokh.html.

Setiawan, A. R. (2013, 17 Oktober). Pangeran Ternistakan. Kirana $\mathscr{V}$ Azalea. URL: https://adibrs.blogspot.com/2013/10/prabowo.html.

Setiawan, A. R. (2013, 06 November). Cendekiawan Picisan. Kirana $\mathscr{V}$ Azalea. URL: https://adibrs.blogspot.com/2013/11/yohanes.html.

Setiawan, A. R. (2013, 14 November). Karbala. Kirana $\mathscr{V}$ Azalea. URL: https://adibrs.blogspot.com/2013/11/karbala.html.

Setiawan, A. R. (2013, 20 Desember). Natal. Kirana $\mathscr{V}$ Azalea. URL: https://adibrs.blogspot.com/2013/12/natal.html.

Setiawan, A. R. (2014, 16 Februari). Valentino Magnifico. Kirana $\mathscr{V}$ Azalea. URL: https://adibrs.blogspot.com/2014/02/vale.html.

Setiawan, A. R. (2014, 27 Februari). Cherry Belle. Kirana $\mathscr{V}$ Azalea. URL: https://adibrs.blogspot.com/2014/02/cherrybelle.html.

Setiawan, A. R. (2014, 26 Maret). Dari Guru IPA ke Guru IPA. Kirana $\mathscr{V}$ Azalea. URL: https://adibrs.blogspot.com/2014/03/ipa.html.

Setiawan, A. R. (2014, 19 April). Not the Next Anyone. Kirana $\mathscr{V}$ Azalea. URL: https://adibrs.blogspot.com/2014/04/maria.html.

Setiawan, A. R. (2014, 26 Mei). Risalah Kasidah. Kirana $\mathscr{V}$ Azalea. URL: https://adibrs.blogspot.com/2014/05/dhani.html.

Setiawan, A. R. (2014, 02 Juni). Melantan Warisan Kaisar Telantar. Kirana $\mathscr{P}$ Azalea. URL: https://adibrs.blogspot.com/2014/06/ibrahim.html.

Setiawan, A. R. (2014, 16 Agustus). Popularitas adalah Tuhan. Kirana $\mathscr{P}$ Azalea. URL: https://adibrs.blogspot.com/2014/08/madonna.html.

Setiawan, A. R. (2014, 26 Agustus). Selatan Jakarta. Kirana $\mathscr{V}$ Azalea. URL: https://adibrs.blogspot.com/2014/08/airin.html.

Setiawan, A. R. (2014, 28 Oktober). Membaca Julia. Kirana $\mathscr{V}$ Azalea. URL: https://adibrs.blogspot.com/2014/10/julia.html.

Setiawan, A. R. (2014, 31 Oktober). Hida. Kirana $\mathscr{V}$ Azalea. URL: https://adibrs.blogspot.com/2014/10/hida.html.

Setiawan, A. R. (2014, 17 November). Warga Indonesia Keturunan Tionghoa. Kirana $\mathcal{V}$ Azalea. URL: https://adibrs.blogspot.com/2014/11/china.html.

Setiawan, A. R. (2014, 29 Desember). Lemah yang Melemahkan. Kirana $\mathcal{V}$ Azalea. URL: https://adibrs.blogspot.com/2014/12/roro.html.

Setiawan, A. R. (2015, 09 Maret). Menyanjung Kirana Semenanjung Malaka. Kirana $\mathcal{V}$ Azalea. URL: https://adibrs.blogspot.com/2015/03/venice.html.

Setiawan, A. R. (2015, 26 Maret). The Great One. Kirana $\mathscr{P}$ Azalea. URL: https://adibrs.blogspot.com/2015/03/zaini.html. 
Setiawan, A. R. (2015, 24 Maret). Luka Daniela Hantuchová. Kirana $\mathscr{V}$ Azalea. URL: https://adibrs.blogspot.com/2015/04/dani.html.

Setiawan, A. R. (2015, 11 Juni). My Peer's Last Gen. Kirana $\mathscr{V}$ Azalea. URL: https://adibrs.blogspot.com/2015/06/maryam.html.

Setiawan, A. R. (2015, 26 September). The Pelantan Society. Kirana $\mathcal{V}$ Azalea. URL: https://adibrs.blogspot.com/2015/09/pelantan.html.

Setiawan, A. R. (2015, 03 Oktober). Restoe Boemi Arjuna. Kirana $\mathcal{V}$ Azalea. URL: https://adibrs.blogspot.com/2015/10/zlatan.html.

Setiawan, A. R. (2015, 31 Oktober). BoA (Best of All). Kirana $\mathscr{P}$ Azalea. URL: https://adibrs.blogspot.com/2015/10/hida.html.

Setiawan, A. R. (2015, 29 November). Mimpi Hidayati. Kirana $\mathcal{V}$ Azalea. URL: https://adibrs.blogspot.com/2015/11/hida.html.

Setiawan, A. R. (2015, 24 Desember). Penggemuruh Gemuruh. Kirana $\mathscr{V}$ Azalea. URL: https://adibrs.blogspot.com/2015/12/hurd.html.

Setiawan, A. R. (2016, 22 Januari). Dari Mesopotamia ke Mesopotamia. Kirana $\mathcal{V}$ Azalea. URL: https://adibrs.blogspot.com/2016/01/asia.html.

Setiawan, A. R. (2016, 17 Februari). Menulis Paris. Kirana $\mathscr{V}$ Azalea. URL: https://adibrs.blogspot.com/2016/02/ph.html.

Setiawan, A. R. (2016, 17 Februari). PARIS. Kirana $\mathscr{V}$ Azalea. URL: https://adibrs.blogspot.com/2016/02/paris.html.

Setiawan, A. R. (2016, 09 Maret). Ionia. Kirana $\mathscr{V}$ Azalea. URL: https://adibrs.blogspot.com/2016/03/ionia.html.

Setiawan, A. R. (2016, 26 Maret). Dua Utama. Kirana $\mathscr{V}$ Azalea. URL: https://adibrs.blogspot.com/2016/03/au.html.

Setiawan, A. R. (2016, 08 April). Ais .... Kirana $\mathcal{V}$ Azalea. URL: https://adibrs.blogspot.com/2016/04/ais.html.

Setiawan, A. R. (2016, 26 Mei). Catatan Picisan. Kirana $\mathscr{V}$ Azalea. URL: https://adibrs.blogspot.com/2016/05/dewa19.html.

Setiawan, A. R. (2016, 11 Juni). Menganyam Iyam. Kirana $\mathscr{P}$ Azalea. URL: https://adibrs.blogspot.com/2016/06/maryam.html.

Setiawan, A. R. (2016, 15 Juli). Dari Yuli Hingga Julia. Kirana $\mathscr{V}$ Azalea. URL: https://adibrs.blogspot.com/2016/07/yuli.html.

Setiawan, A. R. (2016, 23 Juli). Kamu Dalam aku. Kirana $\mathscr{V}$ Azalea. URL: https://adibrs.blogspot.com/2016/07/bom.html.

Setiawan, A. R. (2016, 06 Agustus). Mbak Nong. Kirana $\mathscr{V}$ Azalea. URL: https://adibrs.blogspot.com/2016/08/nong.html.

Setiawan, A. R. (2016, 26 September). 3. Kirana $\mathscr{V}$ Azalea. URL: https://adibrs.blogspot.com/2016/09/trinfinity.html.

Setiawan, A. R. (2016, 31 Oktober). Immortal Friendship. Kirana $\mathscr{V}$ Azalea. URL: https://adibrs.blogspot.com/2016/10/friendship.html.

Setiawan, A. R. (2016, 17 November). K2. Kirana $\mathscr{V}$ Azalea. URL: https://adibrs.blogspot.com/2016/11/kaka.html.

Setiawan, A. R. (2016, 24 November). Diving Epic Being Antique. Kirana $\mathscr{V}$ Azalea. URL: https://adibrs.blogspot.com/2016/11/xxi.html.

Setiawan, A. R. (2016, 29 November). Stronger. Kirana $\mathcal{V}$ Azalea. URL: https://adibrs.blogspot.com/2016/11/hida.html. 
Setiawan, A. R. (2016, 18 Desember). Reach Research. Kirana $\mathscr{P}$ Azalea. URL: https://adibrs.blogspot.com/2016/12/research.html.

Setiawan, A. R. (2017, 23 Januari). Mengemong Pesona Nong Mahmada. Kirana $\mathscr{V}$ Azalea. URL: https://adibrs.blogspot.com/2017/01/nong.html.

Setiawan, A. R. (2017, 15 Februari). Butcah Chuniez. Kirana $\mathcal{V}$ Azalea. URL: https://adibrs.blogspot.com/2017/02/thata.html.

Setiawan, A. R. (2017, 23 Maret). Mbak Nong. Kirana $\mathscr{V}$ Azalea. URL: https://adibrs.blogspot.com/2017/03/nong.html.

Setiawan, A. R. (2017, 30 Maret). Guru yang Menyapih. Kirana $\mathscr{P}$ Azalea. URL: https://adibrs.blogspot.com/2017/03/nongdarolmahmada.html.

Setiawan, A. R. (2017, 11 Mei). My Way Rhapsody!. Kirana $\mathscr{V}$ Azalea. URL: https://adibrs.blogspot.com/2017/05/islam.html.

Setiawan, A. R. (2017, 01 Mei). Aisha. Kirana $\mathscr{V}$ Azalea. URL: https://adibrs.blogspot.com/2017/06/aisha.html.

Setiawan, A. R. (2017, 05 Juni). One More Light. Kirana $\mathscr{V}$ Azalea. URL: https://adibrs.blogspot.com/2017/06/lp.html.

Setiawan, A. R. (2017, 10 Juni). Selamat Jalan Mamita Jupe. Kirana $\mathscr{V}$ Azalea. URL: https://adibrs.blogspot.com/2017/06/yuli.html.

Setiawan, A. R. (2017, 11 Juni). Sisi Mengagumkan Jupe. Kirana $\mathscr{V}$ Azalea. URL: https://adibrs.blogspot.com/2017/06/jupe.html.

Setiawan, A. R. (2017, 30 Juni). Meniti Ilmuwati (Scholaristi). Kirana $\mathscr{V}$ Azalea. URL: https://adibrs.blogspot.com/2017/06/scholaristi.html.

Setiawan, A. R. (2017, 10 Desember). Godly Nationalism. Kirana $\mathscr{P}$ Azalea. URL: https://adibrs.blogspot.com/2017/12/godly-nationalism.html.

Setiawan, A. R. (2017, 21 Desember). Menjadi Istri Mandiri ala Ienas Tsuroiya. Kirana $\mathfrak{V}$ Azalea. URL: https://adibrs.blogspot.com/2017/12/tsuroiya.html.

Setiawan, A. R. (2017, 22 Desember). Amazing Grace. Kirana $\mathscr{V}$ Azalea. URL: https://adibrs.blogspot.com/2017/12/grace.html.

Setiawan, A. R. (2017, 23 Desember). Eny Rochmawati Octaviani. Kirana $\mathscr{P}$ Azalea. URL: https://adibrs.blogspot.com/2017/12/tata.html.

Setiawan, A. R. (2017, 30 Desember). Manusia adalah Makhluk Berperasaan. Kirana $\mathscr{V}$ Azalea. URL: https://adibrs.blogspot.com/2017/12/manusia-adalah-makhlukberperasaan.html.

Setiawan, A. R. (2017, 31 Desember). Clara Ng: An Author for Our Time. Kirana $\mathscr{P}$ Azalea. URL: https://adibrs.blogspot.com/2017/12/clara-ng.html.

Setiawan, A. R. (2018, 28 Juli). Oza Kioza. Kirana $\mathcal{V}$ Azalea. URL: https://adibrs.blogspot.com/2018/07/oza-kioza.html.

Setiawan, A. R. (2018, tanggal bulan). Surely You're Joking, Mrs. Ilmy!. Kirana $\mathscr{V}$ Azalea. URL: https://adibrs.blogspot.com/2018/01/surotul-ilmiyah.html.

\section{PrePrint Manuscripts}

Setiawan, A. R. (2020, May 12). Introducing the Indonesian Education System. Thesis Commons. DOI: https://doi.org/10.31237/osf.io/ygt5c

Setiawan, A. R. (2020, May 7). Discovering the Fundamental Problem of Four Methods to Analyze Data. Thesis Commons. DOI: https://doi.org/10.31237/osf.io/h953y

Setiawan, A. R. (2020, May 6). Menyibak Makna Karya Fadhilaturrahmi. LIS Scholarship Archive. DOI: https://doi.org/10.31229/osf.io/65y4z 
Setiawan, A. R. (2020, May 6). Discovering the Meaning of Fadhilaturrahmi's Work. Thesis Commons. DOI: https://doi.org/10.31237/osf.io/krf7z

Feldman, DarHalevy; \& Setiawan, A. R. (2020, April 24). Education in Israel. Thesis Commons. DOI: https://doi.org/10.31237/osf.io/62shg

Setiawan, A. R. (2020, April 18). Musyāfahah al-Qur'ān Melalui Media Elektronik. Thesis Commons. URL: https://thesiscommons.org/ntjp9/

Setiawan, A. R. (2020, April 14). Jalāl al-Dīn 'Abd al-Roḥmān ibn Abī Bakr al-Suyūṭ̂. SocArXiv. DOI: https://doi.org/10.31235/osf.io/5zf9v

Setiawan, A. R. (2020, April 14). Commodification of the Sexuality in Kim Kardashian's Instagram Posts. SocArXiv. DOI: https://doi.org/10.31235/osf.io/kd6au

Velasufah, Whasfi; \& Setiawan, A. R. (2020, April 13). Nilai Pesantren Sebagai Dasar Pendidikan Karakter. Thesis Commons. DOI: https://doi.org/10.31237/osf.io/hq6kz

Setiawan, A. R. (2020, April 13). Commodification of the Sexuality in Kim Kardashian's Instagram Posts. Thesis Commons. URL: https://thesiscommons.org/mf7nw/

Setiawan, A. R. (2020, April 13). مبادئ اللغة العربية. Thesis Commons. DOI: https://doi.org/10.31237/osf.io/2gvjf

Siayah, Syarofis; \& Setiawan, A. R. (2020, April 13). A Brief Explanation of Science Education. EdArXiv. DOI: https://doi.org/10.35542/osf.io/2evn3

Siayah, Syarofis; \& Setiawan, A. R. (2020, April 13). A Brief Explanation of Science Education. Thesis Commons. DOI: https://doi.org/10.31237/osf.io/wkvsn

Setiawan, A. R.; \& Ilmiyah, Surotul. (2020, April 13). Multiple Intelligences Based on Neuroscience. Thesis Commons. DOI: https://doi.org/10.31237/osf.io/e9fyu

Setiawan, A. R.; \& Ilmiyah, Surotul. (2020, April 13). Kecerdasan Majemuk Berdasarkan Neurosains. EdArXiv. DOI: https://doi.org/10.35542/osf.io/rj2fe

Setiawan, A. R. (2020, April 9). Islamic Education in Southeast Asia. EdArXiv. DOI: https://doi.org/10.35542/osf.io/dnjqv

Setiawan, A. R. (2020, April 9). Islamic Education in Southeast Asia. Thesis Commons. DOI: https://doi.org/10.31237/osf.io/e794d

Ilmiyah, Surotul; \& Setiawan, A. R. (2020, April 7). Students' Worksheet for Distance Learning Based on Scientific Literacy in the Topic Coronavirus Disease 2019 (COVID-19). Thesis Commons. DOI: https://doi.org/10.31237/osf.io/fpg4j

Ilmiyah, Surotul; \& Setiawan, A. R. (2020, April 7). Students' Worksheet for Distance Learning Based on Scientific Literacy in the Topic Coronavirus Disease 2019 (COVID-19). EdArXiv. DOI: https://doi.org/10.35542/osf.io/wyz5v

Setiawan, A. R.; \& Ilmiyah, Surotul. (2020, April 7). Lembar Kegiatan Siswa untuk Pembelajaran Jarak Jauh Berdasarkan Literasi Saintifik pada Topik Penyakit Coronavirus 2019 (COVID-19). EdArXiv. DOI: https://doi.org/10.35542/osf.io/h4632

Setiawan, A. R. (2020, April 5). The Arrogant One. Thesis Commons. DOI: https://doi.org/10.31237/osf.io/8nmku

Setiawan, A. R. (2020, April 4). Grace Natalie Louisa. SocArXiv. DOI: https://doi.org/10.31235/osf.io/zwf6g

Setiawan, A. R. (2020, April 4). Grace Natalie Louisa. Thesis Commons. DOI: https://doi.org/10.31237/osf.io/u3mxv

Setiawan, A. R. (2020, April 3). Sharifah Halimah Alaydrus : a female preachers for our time. SocArXiv. DOI: https://doi.org/10.31235/osf.io/zb8qe

Setiawan, A. R. (2020, April 2). Desain Pembelajaran untuk Membimbing Siswa Sekolah Dasar dalam Memperoleh Literasi Saintifik. EdArXiv. DOI: https://doi.org/10.35542/osf.io/u59f8 
Setiawan, A. R. (2020, April 2). What is the Best Way to Analyze Pre-Post Data?. EdArXiv. DOI: https://doi.org/10.35542/osf.io/h4e6q

Setiawan, A. R. (2020, April 2). JUPE My Uncut Story. Open Science Framework (OSF). DOI: https://doi.org/10.31219/osf.io/qdxga

Setiawan, A. R. (2020, April 1). Syarifah Halimah Alaydrus. Thesis Commons. DOI: https://doi.org/10.31237/osf.io/xbmcs

Setiawan, A. R. (2020, April 1). Sharifah Halimah Alaydrus. Thesis Commons. DOI: https://doi.org/10.31237/osf.io/fp79c

Setiawan, A. R. (2019, October 8). Biografi Clara Ng Perempuan Penulis Asal Indonesia. PsyArXiv. DOI: https://doi.org/10.31234/osf.io/yk8sx

Setiawan, A. R., \& Saputri, W. E. (2020). Assessment Instrument of Financial Literacy for Fiqh Mu'āmalāt Learning Based on Kitab Kuning.

Setiawan, A. R., \& Saputri, W. E. (2020). Instrumen Penilaian Literasi Finansial untuk Pembelajaran Fiqh Mu'āmalāt Berbasis Kitab Kuning.

Saputri, W. E., \& Setiawan, A. R. (2020). Potret Pelestarian Lingkungan Alam Berdasarkan Kearifan Lokal Masyarakat Colo.

Saputri, W. E., \& Setiawan, A. R. (2020). Pelestarian Lingkungan Hidup Berdasarkan Kearifan Lokal Masyarakat Colo.

Setiawan, A. R., \& Saputri, W. E. (2019). STEAM Education: background, framework, and characteristics. EdArXiv. December, 27.

Siayah, S., Setiawan, A. R., \& Saputri, W. E. (2019). The Profile of Students' Competencies in Biology Learning-Scientific Literacy Oriented.

Siayah, S., Setiawan, A. R., \& Saputri, W. E. (2019). Profil Kompetensi Siswa Dalam Pembelajaran Biologi Berorientasi Literasi Saintifik.

Setiawan, A. R., \& Saputri, W. E. (2019). Designing Assessment Instrument for Environmental Learning That Is Scientific Literacy-oriented.

Setiawan, A. R., \& Saputri, W. E. (2019). Analysis on Validity and Reliability of Science Motivation Questionnaire II (SMQ-II) Bahasa Indonesia Version.

Saputri, W. E., \& Setiawan, A. R. (2019). Kuesioner Motivasi Perkuliahan Manajemen.

Saputri, W. E., \& Setiawan, A. R. (2019). Dampak Wisata Gunung Muria Terhadap Perekonomian Masyarakat Colo.

Setiawan, A. R., \& Saputri, W. E. (2019). ESTIMASI DAMPAK SEKTOR PARIWISATA DI GUNUNG MURIA TERHADAP PEREKONOMIAN MASYARAKAT DESA COLO BERDASARKAN MULTIPLIER EFFECT.

Setiawan, A. R., \& Saputri, W. E. (2019). Soal Literasi Finansial untuk Pembelajaran Fikih Muamalah di Tingkat Menengah.

Setiawan, A. R., \& Saputri, W. E. (2019). Financial Literacy Test for Fikih Muamalah Learning in Secondary Education (No. cqtd2). Center for Open Science.

Setiawan, A. R., \& Saputri, W. E. (2020). Assessment Instrument of Financial Literacy for Fiqh Mu'āmalāt Learning Based on Kitab Kuning.

Setiawan, A. R., \& Saputri, W. E. (2020). Instrumen Penilaian Literasi Finansial untuk Pembelajaran Fiqh Mu'āmalāt Berbasis Kitab Kuning.

Saputri, W. E., \& Setiawan, A. R. (2020). Potret Pelestarian Lingkungan Alam Berdasarkan Kearifan Lokal Masyarakat Colo.

Saputri, W. E., \& Setiawan, A. R. (2020). Pelestarian Lingkungan Hidup Berdasarkan Kearifan Lokal Masyarakat Colo.

Setiawan, A. R., \& Saputri, W. E. (2019). STEAM Education: background, framework, and characteristics. EdArXiv. December, 27.

Siayah, S., Setiawan, A. R., \& Saputri, W. E. (2019). The Profile of Students' Competencies in Biology Learning-Scientific Literacy Oriented. 
Siayah, S., Setiawan, A. R., \& Saputri, W. E. (2019). Profil Kompetensi Siswa Dalam Pembelajaran Biologi Berorientasi Literasi Saintifik.

Setiawan, A. R., \& Saputri, W. E. (2019). Designing Assessment Instrument for Environmental Learning That Is Scientific Literacy-oriented.

Setiawan, A. R., \& Saputri, W. E. (2019). Analysis on Validity and Reliability of Science Motivation Questionnaire II (SMQ-II) Bahasa Indonesia Version.

Saputri, W. E., \& Setiawan, A. R. (2019). Kuesioner Motivasi Perkuliahan Manajemen.

Saputri, W. E., \& Setiawan, A. R. (2019). Dampak Wisata Gunung Muria Terhadap Perekonomian Masyarakat Colo.

Setiawan, A. R., \& Saputri, W. E. (2019). ESTIMASI DAMPAK SEKTOR PARIWISATA DI GUNUNG MURIA TERHADAP PEREKONOMIAN MASYARAKAT DESA COLO BERDASARKAN MULTIPLIER EFFECT.

Setiawan, A. R., \& Saputri, W. E. (2019). Soal Literasi Finansial untuk Pembelajaran Fikih Muamalah di Tingkat Menengah.

Setiawan, A. R., \& Saputri, W. E. (2019). Financial Literacy Test for Fikih Muamalah Learning in Secondary Education (No. cqtd2). Center for Open Science.

Setiawan, A. R., \& Saputri, W. E. (2020). Assessment Instrument of Financial Literacy for Fiqh Mu'āmalāt Learning Based on Kitab Kuning.

Setiawan, A. R., \& Saputri, W. E. (2020). Instrumen Penilaian Literasi Finansial untuk Pembelajaran Fiqh Mu'āmalāt Berbasis Kitab Kuning.

Saputri, W. E., \& Setiawan, A. R. (2020). Potret Pelestarian Lingkungan Alam Berdasarkan Kearifan Lokal Masyarakat Colo.

Saputri, W. E., \& Setiawan, A. R. (2020). Pelestarian Lingkungan Hidup Berdasarkan Kearifan Lokal Masyarakat Colo.

Setiawan, A. R., \& Saputri, W. E. (2019). STEAM Education: background, framework, and characteristics. EdArXiv. December, 27.

Siayah, S., Setiawan, A. R., \& Saputri, W. E. (2019). The Profile of Students' Competencies in Biology Learning-Scientific Literacy Oriented.

Siayah, S., Setiawan, A. R., \& Saputri, W. E. (2019). Profil Kompetensi Siswa Dalam Pembelajaran Biologi Berorientasi Literasi Saintifik.

Setiawan, A. R., \& Saputri, W. E. (2019). Designing Assessment Instrument for Environmental Learning That Is Scientific Literacy-oriented.

Setiawan, A. R., \& Saputri, W. E. (2019). Analysis on Validity and Reliability of Science Motivation Questionnaire II (SMQ-II) Bahasa Indonesia Version.

Saputri, W. E., \& Setiawan, A. R. (2019). Kuesioner Motivasi Perkuliahan Manajemen.

Saputri, W. E., \& Setiawan, A. R. (2019). Dampak Wisata Gunung Muria Terhadap Perekonomian Masyarakat Colo.

Setiawan, A. R., \& Saputri, W. E. (2019). ESTIMASI DAMPAK SEKTOR PARIWISATA DI GUNUNG MURIA TERHADAP PEREKONOMIAN MASYARAKAT DESA COLO BERDASARKAN MULTIPLIER EFFECT.

Setiawan, A. R., \& Saputri, W. E. (2019). Soal Literasi Finansial untuk Pembelajaran Fikih Muamalah di Tingkat Menengah.

Setiawan, A. R., \& Saputri, W. E. (2019). Financial Literacy Test for Fikih Muamalah Learning in Secondary Education (No. cqtd2). Center for Open Science.

Setiawan, A. R., \& Saputri, W. E. (2020). Assessment Instrument of Financial Literacy for Fiqh Mu'āmalāt Learning Based on Kitab Kuning.

Setiawan, A. R., \& Saputri, W. E. (2020). Instrumen Penilaian Literasi Finansial untuk Pembelajaran Fiqh Mu'āmalāt Berbasis Kitab Kuning.

Saputri, W. E., \& Setiawan, A. R. (2020). Potret Pelestarian Lingkungan Alam Berdasarkan Kearifan Lokal Masyarakat Colo. 
Saputri, W. E., \& Setiawan, A. R. (2020). Pelestarian Lingkungan Hidup Berdasarkan Kearifan Lokal Masyarakat Colo.

Setiawan, A. R., \& Saputri, W. E. (2019). STEAM Education: background, framework, and characteristics. EdArXiv. December, 27.

Siayah, S., Setiawan, A. R., \& Saputri, W. E. (2019). The Profile of Students' Competencies in Biology Learning-Scientific Literacy Oriented.

Siayah, S., Setiawan, A. R., \& Saputri, W. E. (2019). Profil Kompetensi Siswa Dalam Pembelajaran Biologi Berorientasi Literasi Saintifik.

Setiawan, A. R., \& Saputri, W. E. (2019). Designing Assessment Instrument for Environmental Learning That Is Scientific Literacy-oriented.

Setiawan, A. R., \& Saputri, W. E. (2019). Analysis on Validity and Reliability of Science Motivation Questionnaire II (SMQ-II) Bahasa Indonesia Version.

Saputri, W. E., \& Setiawan, A. R. (2019). Kuesioner Motivasi Perkuliahan Manajemen.

Saputri, W. E., \& Setiawan, A. R. (2019). Dampak Wisata Gunung Muria Terhadap Perekonomian Masyarakat Colo.

Setiawan, A. R., \& Saputri, W. E. (2019). ESTIMASI DAMPAK SEKTOR PARIWISATA DI GUNUNG MURIA TERHADAP PEREKONOMIAN MASYARAKAT DESA COLO BERDASARKAN MULTIPLIER EFFECT.

Setiawan, A. R., \& Saputri, W. E. (2019). Soal Literasi Finansial untuk Pembelajaran Fikih Muamalah di Tingkat Menengah.

Setiawan, A. R., \& Saputri, W. E. (2019). Financial Literacy Test for Fikih Muamalah Learning in Secondary Education (No. cqtd2). Center for Open Science.

Setiawan, A. R., \& Saputri, W. E. (2020). Assessment Instrument of Financial Literacy for Fiqh Mu'āmalāt Learning Based on Kitab Kuning.

Setiawan, A. R., \& Saputri, W. E. (2020). Instrumen Penilaian Literasi Finansial untuk Pembelajaran Fiqh Mu'āmalāt Berbasis Kitab Kuning.

Saputri, W. E., \& Setiawan, A. R. (2020). Potret Pelestarian Lingkungan Alam Berdasarkan Kearifan Lokal Masyarakat Colo.

Saputri, W. E., \& Setiawan, A. R. (2020). Pelestarian Lingkungan Hidup Berdasarkan Kearifan Lokal Masyarakat Colo.

Setiawan, A. R., \& Saputri, W. E. (2019). STEAM Education: background, framework, and characteristics. EdArXiv. December, 27.

Siayah, S., Setiawan, A. R., \& Saputri, W. E. (2019). The Profile of Students' Competencies in Biology Learning-Scientific Literacy Oriented.

Siayah, S., Setiawan, A. R., \& Saputri, W. E. (2019). Profil Kompetensi Siswa Dalam Pembelajaran Biologi Berorientasi Literasi Saintifik.

Setiawan, A. R., \& Saputri, W. E. (2019). Designing Assessment Instrument for Environmental Learning That Is Scientific Literacy-oriented.

Setiawan, A. R., \& Saputri, W. E. (2019). Analysis on Validity and Reliability of Science Motivation Questionnaire II (SMQ-II) Bahasa Indonesia Version.

Saputri, W. E., \& Setiawan, A. R. (2019). Kuesioner Motivasi Perkuliahan Manajemen.

Saputri, W. E., \& Setiawan, A. R. (2019). Dampak Wisata Gunung Muria Terhadap Perekonomian Masyarakat Colo.

Setiawan, A. R., \& Saputri, W. E. (2019). ESTIMASI DAMPAK SEKTOR PARIWISATA DI GUNUNG MURIA TERHADAP PEREKONOMIAN MASYARAKAT DESA COLO BERDASARKAN MULTIPLIER EFFECT.

Setiawan, A. R., \& Saputri, W. E. (2019). Soal Literasi Finansial untuk Pembelajaran Fikih Muamalah di Tingkat Menengah.

Setiawan, A. R., \& Saputri, W. E. (2019). Financial Literacy Test for Fikih Muamalah Learning in Secondary Education (No. cqtd2). Center for Open Science. 
Setiawan, A. R., \& Saputri, W. E. (2020). Assessment Instrument of Financial Literacy for Fiqh Mu'āmalāt Learning Based on Kitab Kuning.

Setiawan, A. R., \& Saputri, W. E. (2020). Instrumen Penilaian Literasi Finansial untuk Pembelajaran Fiqh Mu'āmalāt Berbasis Kitab Kuning.

Saputri, W. E., \& Setiawan, A. R. (2020). Potret Pelestarian Lingkungan Alam Berdasarkan Kearifan Lokal Masyarakat Colo.

Saputri, W. E., \& Setiawan, A. R. (2020). Pelestarian Lingkungan Hidup Berdasarkan Kearifan Lokal Masyarakat Colo.

Setiawan, A. R., \& Saputri, W. E. (2019). STEAM Education: background, framework, and characteristics. EdArXiv. December, 27.

Siayah, S., Setiawan, A. R., \& Saputri, W. E. (2019). The Profile of Students' Competencies in Biology Learning-Scientific Literacy Oriented.

Siayah, S., Setiawan, A. R., \& Saputri, W. E. (2019). Profil Kompetensi Siswa Dalam Pembelajaran Biologi Berorientasi Literasi Saintifik.

Setiawan, A. R., \& Saputri, W. E. (2019). Designing Assessment Instrument for Environmental Learning That Is Scientific Literacy-oriented.

Setiawan, A. R., \& Saputri, W. E. (2019). Analysis on Validity and Reliability of Science Motivation Questionnaire II (SMQ-II) Bahasa Indonesia Version.

Saputri, W. E., \& Setiawan, A. R. (2019). Kuesioner Motivasi Perkuliahan Manajemen.

Saputri, W. E., \& Setiawan, A. R. (2019). Dampak Wisata Gunung Muria Terhadap Perekonomian Masyarakat Colo.

Setiawan, A. R., \& Saputri, W. E. (2019). ESTIMASI DAMPAK SEKTOR PARIWISATA DI GUNUNG MURIA TERHADAP PEREKONOMIAN MASYARAKAT DESA COLO BERDASARKAN MULTIPLIER EFFECT.

Setiawan, A. R., \& Saputri, W. E. (2019). Soal Literasi Finansial untuk Pembelajaran Fikih Muamalah di Tingkat Menengah.

Setiawan, A. R., \& Saputri, W. E. (2019). Financial Literacy Test for Fikih Muamalah Learning in Secondary Education (No. cqtd2). Center for Open Science.

Setiawan, A. R., \& Saputri, W. E. (2020). Assessment Instrument of Financial Literacy for Fiqh Mu'āmalāt Learning Based on Kitab Kuning.

Setiawan, A. R., \& Saputri, W. E. (2020). Instrumen Penilaian Literasi Finansial untuk Pembelajaran Fiqh Mu'āmalāt Berbasis Kitab Kuning.

Saputri, W. E., \& Setiawan, A. R. (2020). Potret Pelestarian Lingkungan Alam Berdasarkan Kearifan Lokal Masyarakat Colo.

Saputri, W. E., \& Setiawan, A. R. (2020). Pelestarian Lingkungan Hidup Berdasarkan Kearifan Lokal Masyarakat Colo.

Setiawan, A. R., \& Saputri, W. E. (2019). STEAM Education: background, framework, and characteristics. EdArXiv. December, 27.

Siayah, S., Setiawan, A. R., \& Saputri, W. E. (2019). The Profile of Students' Competencies in Biology Learning-Scientific Literacy Oriented.

Siayah, S., Setiawan, A. R., \& Saputri, W. E. (2019). Profil Kompetensi Siswa Dalam Pembelajaran Biologi Berorientasi Literasi Saintifik.

Setiawan, A. R., \& Saputri, W. E. (2019). Designing Assessment Instrument for Environmental Learning That Is Scientific Literacy-oriented.

Setiawan, A. R., \& Saputri, W. E. (2019). Analysis on Validity and Reliability of Science Motivation Questionnaire II (SMQ-II) Bahasa Indonesia Version.

Saputri, W. E., \& Setiawan, A. R. (2019). Kuesioner Motivasi Perkuliahan Manajemen.

Saputri, W. E., \& Setiawan, A. R. (2019). Dampak Wisata Gunung Muria Terhadap Perekonomian Masyarakat Colo. 
Setiawan, A. R., \& Saputri, W. E. (2019). ESTIMASI DAMPAK SEKTOR PARIWISATA DI GUNUNG MURIA TERHADAP PEREKONOMIAN MASYARAKAT DESA COLO BERDASARKAN MULTIPLIER EFFECT.

Setiawan, A. R., \& Saputri, W. E. (2019). Soal Literasi Finansial untuk Pembelajaran Fikih Muamalah di Tingkat Menengah.

Setiawan, A. R., \& Saputri, W. E. (2019). Financial Literacy Test for Fikih Muamalah Learning in Secondary Education (No. cqtd2). Center for Open Science.

Setiawan, A. R., \& Saputri, W. E. (2020). Assessment Instrument of Financial Literacy for Fiqh Mu'āmalāt Learning Based on Kitab Kuning.

Setiawan, A. R., \& Saputri, W. E. (2020). Instrumen Penilaian Literasi Finansial untuk Pembelajaran Fiqh Mu'āmalāt Berbasis Kitab Kuning.

Saputri, W. E., \& Setiawan, A. R. (2020). Potret Pelestarian Lingkungan Alam Berdasarkan Kearifan Lokal Masyarakat Colo.

Saputri, W. E., \& Setiawan, A. R. (2020). Pelestarian Lingkungan Hidup Berdasarkan Kearifan Lokal Masyarakat Colo.

Setiawan, A. R., \& Saputri, W. E. (2019). STEAM Education: background, framework, and characteristics. EdArXiv. December, 27.

Siayah, S., Setiawan, A. R., \& Saputri, W. E. (2019). The Profile of Students' Competencies in Biology Learning-Scientific Literacy Oriented.

Siayah, S., Setiawan, A. R., \& Saputri, W. E. (2019). Profil Kompetensi Siswa Dalam Pembelajaran Biologi Berorientasi Literasi Saintifik.

Setiawan, A. R., \& Saputri, W. E. (2019). Designing Assessment Instrument for Environmental Learning That Is Scientific Literacy-oriented.

Setiawan, A. R., \& Saputri, W. E. (2019). Analysis on Validity and Reliability of Science Motivation Questionnaire II (SMQ-II) Bahasa Indonesia Version.

Saputri, W. E., \& Setiawan, A. R. (2019). Kuesioner Motivasi Perkuliahan Manajemen.

Saputri, W. E., \& Setiawan, A. R. (2019). Dampak Wisata Gunung Muria Terhadap Perekonomian Masyarakat Colo.

Setiawan, A. R., \& Saputri, W. E. (2019). ESTIMASI DAMPAK SEKTOR PARIWISATA DI GUNUNG MURIA TERHADAP PEREKONOMIAN MASYARAKAT DESA COLO BERDASARKAN MULTIPLIER EFFECT.

Setiawan, A. R., \& Saputri, W. E. (2019). Soal Literasi Finansial untuk Pembelajaran Fikih Muamalah di Tingkat Menengah.

Setiawan, A. R., \& Saputri, W. E. (2019). Financial Literacy Test for Fikih Muamalah Learning in Secondary Education (No. cqtd2). Center for Open Science.

Setiawan, A. R., \& Saputri, W. E. (2020). Assessment Instrument of Financial Literacy for Fiqh Mu'āmalāt Learning Based on Kitab Kuning.

Setiawan, A. R., \& Saputri, W. E. (2020). Instrumen Penilaian Literasi Finansial untuk Pembelajaran Fiqh Mu'āmalāt Berbasis Kitab Kuning.

Saputri, W. E., \& Setiawan, A. R. (2020). Potret Pelestarian Lingkungan Alam Berdasarkan Kearifan Lokal Masyarakat Colo.

Saputri, W. E., \& Setiawan, A. R. (2020). Pelestarian Lingkungan Hidup Berdasarkan Kearifan Lokal Masyarakat Colo.

Setiawan, A. R., \& Saputri, W. E. (2019). STEAM Education: background, framework, and characteristics. EdArXiv. December, 27.

Siayah, S., Setiawan, A. R., \& Saputri, W. E. (2019). The Profile of Students' Competencies in Biology Learning-Scientific Literacy Oriented.

Siayah, S., Setiawan, A. R., \& Saputri, W. E. (2019). Profil Kompetensi Siswa Dalam Pembelajaran Biologi Berorientasi Literasi Saintifik. 
Setiawan, A. R., \& Saputri, W. E. (2019). Designing Assessment Instrument for Environmental Learning That Is Scientific Literacy-oriented.

Setiawan, A. R., \& Saputri, W. E. (2019). Analysis on Validity and Reliability of Science Motivation Questionnaire II (SMQ-II) Bahasa Indonesia Version.

Saputri, W. E., \& Setiawan, A. R. (2019). Kuesioner Motivasi Perkuliahan Manajemen.

Saputri, W. E., \& Setiawan, A. R. (2019). Dampak Wisata Gunung Muria Terhadap Perekonomian Masyarakat Colo.

Setiawan, A. R., \& Saputri, W. E. (2019). ESTIMASI DAMPAK SEKTOR PARIWISATA DI GUNUNG MURIA TERHADAP PEREKONOMIAN MASYARAKAT DESA COLO BERDASARKAN MULTIPLIER EFFECT.

Setiawan, A. R., \& Saputri, W. E. (2019). Soal Literasi Finansial untuk Pembelajaran Fikih Muamalah di Tingkat Menengah.

Setiawan, A. R., \& Saputri, W. E. (2019). Financial Literacy Test for Fikih Muamalah Learning in Secondary Education (No. cqtd2). Center for Open Science.

Setiawan, A. R., \& Saputri, W. E. (2020). Assessment Instrument of Financial Literacy for Fiqh Mu'āmalāt Learning Based on Kitab Kuning.

Setiawan, A. R., \& Saputri, W. E. (2020). Instrumen Penilaian Literasi Finansial untuk Pembelajaran Fiqh Mu'āmalāt Berbasis Kitab Kuning.

Saputri, W. E., \& Setiawan, A. R. (2020). Potret Pelestarian Lingkungan Alam Berdasarkan Kearifan Lokal Masyarakat Colo.

Saputri, W. E., \& Setiawan, A. R. (2020). Pelestarian Lingkungan Hidup Berdasarkan Kearifan Lokal Masyarakat Colo.

Setiawan, A. R., \& Saputri, W. E. (2019). STEAM Education: background, framework, and characteristics. EdArXiv. December, 27.

Siayah, S., Setiawan, A. R., \& Saputri, W. E. (2019). The Profile of Students' Competencies in Biology Learning-Scientific Literacy Oriented.

Siayah, S., Setiawan, A. R., \& Saputri, W. E. (2019). Profil Kompetensi Siswa Dalam Pembelajaran Biologi Berorientasi Literasi Saintifik.

Setiawan, A. R., \& Saputri, W. E. (2019). Designing Assessment Instrument for Environmental Learning That Is Scientific Literacy-oriented.

Setiawan, A. R., \& Saputri, W. E. (2019). Analysis on Validity and Reliability of Science Motivation Questionnaire II (SMQ-II) Bahasa Indonesia Version.

Saputri, W. E., \& Setiawan, A. R. (2019). Kuesioner Motivasi Perkuliahan Manajemen. Saputri, W. E., \& Setiawan, A. R. (2019). Dampak Wisata Gunung Muria Terhadap Perekonomian Masyarakat Colo.

Setiawan, A. R., \& Saputri, W. E. (2019). ESTIMASI DAMPAK SEKTOR PARIWISATA DI GUNUNG MURIA TERHADAP PEREKONOMIAN MASYARAKAT DESA COLO BERDASARKAN MULTIPLIER EFFECT.

Setiawan, A. R., \& Saputri, W. E. (2019). Soal Literasi Finansial untuk Pembelajaran Fikih Muamalah di Tingkat Menengah.

Setiawan, A. R., \& Saputri, W. E. (2019). Financial Literacy Test for Fikih Muamalah Learning in Secondary Education (No. cqtd2). Center for Open Science. 